\title{
PENGARUH RENDAM KAKI AIR HANGAT TERHADAP PERUBAHAN TEKANAN DARAH IBU HAMIL HIPERTENSI
}

\author{
${ }^{1}$ Rika Rahim, ${ }^{2}$ Siti Saadah M., \& ${ }^{3}$ Sariestya Rismawati \\ 1, 2,3 Jurusan Kebidanan Poltekkes Kemenkes Tasikmalaya \\ rika6396@gmail.com
}

\begin{abstract}
Abstrak
Tujuan penelitian adalah untuk mengetahui pengaruh terapi rendam kaki air hangat terhadap perubahan tekanan darah pada ibu hamil hipertensi. Metode penelitian yang digunakan adalah eksperimen dengan jenis penelitian pre-eksperimen dengan pendekatan one group pretest-posttest. Populasi penelitian adalah semua ibu hamil dengan hipertensi sebanyak 24 orang. Teknik pengambilan sampel menggunakan teknik accidental sampling yaitu sebanyak 17 orang. Hasil penelitian menunjukkan rata-rata tekanan darah sebelum diberikan terapi rendam kaki air hangat yaitu sistolik $144,7 \mathrm{mmHg}$, dan diastolik $92,9 \mathrm{mmHg}$. Rata-rata tekanan darah setelah diberikan terapi yaitu sistolik $129,4 \mathrm{mmHg}$, dan diastolik $87,6 \mathrm{mmHg}$. Hasil penelitian menunjukkan bahwa nilai signifikansi tekanan darah sistolik sebesar 0,000 dan tekanan darah diastolik 0,003, $(\alpha<0,05)$, maka $\mathrm{H}_{0}$ ditolak berarti ada pengaruh terapi rendam kaki air hangat terhadap perubahan tekanan darah pada ibu hamil trimester III.
\end{abstract}

Kata Kunci : Ibu hamil, rendam air hangat, tekanan darah

\begin{abstract}
The purpose of this study to determine the effect of warm water foot therapy to changes in blood pressure in pregnant hypertension. The research method used is experiment with preexperiment type research, with one group pretest-posttest approach. The population in this study were all pregnant with hypertension counted 24 people. Sampling technique using accidental sampling technique that is as many as 17 people. The results showed that the average blood pressure before the therapy is given warm a foot soak of warm water that systolic 144,7 $\mathrm{mmHg}$ and diastolic $92,9 \mathrm{mmHg}$. Mean blood pressure after therapy was given systolic 129,4 $\mathrm{mmHg}$ and diastolic $87,6 \mathrm{mmHg}$. The results showed that the significant value of systolic blood pressure of 0.00, and diastolic blood pressure $0.003(\alpha<0,05)$, then $\mathrm{H}_{0}$ rejected which means there is influence of warm water foot therapy against changes in blood pressure in pregnant trimester III.
\end{abstract}

Keywords : pregnant, soak warm water, blood pressure

\section{PENDAHULUAN}

World Health Organization (WHO) memperkirakan 800 perempuan meninggal setiap harinya akibat komplikasi kehamilan dan proses persalinan. Sekitar (80\%) kematian maternal merupakan akibat meningkatnya komplikasi selama kehamilan, persalinan dan setelah persalinan (ICD-10, 2012; WHO, 2014). Menurut laporan WHO tahun 2014 Angka Kematian Ibu (AKI) di dunia 289/100.000 kelahiran hidup (WHO, 2014).
Angka Kematian Ibu (AKI) secara Nasional dari tahun 2010 sebesar 263/100.000 kelahiran hidup, sedangkan pada tahun 2013 AKI di Indonesia sebanyak 346/100.000 kelahiran hidup (Depkes RI, 2010). Berdasarkan Laporan Rutin Program Kesehatan Ibu Tahun 2015 yang diterima dari Dinas Kesehatan Provinsi tercatat Jawa Barat menduduki peringkat tertinggi dalam jumlah AKI, dalam laporan tersebut, jumlah kematian ibu sebanyak 823 kasus (Dinkes Provinsi 
Jawa Barat, 2015), di Kota Tasikmalaya AKI pada tahun 2015 sebanyak 20 kematian, dan pada tahun 2016, dari bulan Januari - Agustus jumlah kematian ibu sebanyak 12 orang.

Penyebab AKI di Kota Tasikmalaya pada tahun 2015 yaitu eklampsia (25\%), jantung (20\%), PEB (10\%), susp asma (10\%), help sindrom (5\%), oedema paru $(5 \%)$, emboli air ketuban (5\%), hypertiroid (5\%), dan lain lain (15\%).

Salah satu masalah kesehatan yang sering muncul selama kehamilan dan dapat menimbulkan komplikasi pada (2$3 \%)$ kehamilan adalah hipertensi. Kejadian hipertensi pada kehamilan sekitar (5-15\%), dan merupakan satu di antara 3 penyebab mortalitas dan morbiditas ibu bersalin di samping infeksi dan perdarahan. Hipertensi dalam kehamilan dapat dialami oleh semua lapisan ibu hamil (Saifudin, 2010).

Hipertensi dapat diobati secara farmakologis dan non-farmakologis. Pengobatan secara farmakologis biasanya menggunakan obat-obatan yang mengandung efek samping. Pengobatan secara non-farmakologis salah satunya dapat dilakukan dengan mengubah gaya hidup yang lebih sehat, melakukan olahraga, diet rendah garam dan melakukan terapi dengan rendam kaki menggunakan air hangat yang bisa dilakukan setiap saat.

Hasil studi pendahuluan yang telah dilakukan kepada 2 orang ibu hamil trimester III dengan hipertensi dalam kehamilan yang dilakukan terapi rendam kaki air hangat $40^{\circ} \mathrm{C}$ selama 20 menit terdapat perubahan tekanan darah yaitudari $140 / 100 \mathrm{mmHg}$ menjadi $130 / 100$ $\mathrm{mmHg}$ dan responden ke dua 150/100 $\mathrm{mmHg}$ menjadi $140 / 90 \mathrm{mmHg}$.

\section{KAJIAN PUSTAKA}

Kehamilan didefinisikan sebagai fertilisasi atau penyatuan dari spermatozoa dan ovum dan dilanjutkan dengan nidasi atau implantasi. Dihitung dari saat fertilisasi hingga lahirnya bayi, kehamilan normal akan berlangsung dalam waktu 40 minggu atau 9 bulan menurut kalender internasional (Saifuddin, 2010).

Hipertensi adalah peningkatan tekanan sistolik sekurang-kurangnya $30 \mathrm{mmHg}$, atau peningkatan tekanan diastolik sekurang-kurangnya $15 \mathrm{mmHg}$. Seseorang dikatakan menderita tekanan darah tinggi atau hipertensi yaitu apabila tekanan darah sistolik $>140 \mathrm{mmHg}$ dan diastolik $>90$ mmhg (Rukiyah dan Yulianti, 2010).

Terapi rendam kaki adalah terapi dengan cara merendam kaki hingga batas 10-15 cm diatas mata kaki menggunakan air hangat. Terapi ini bertujuan untuk meningkatkan aliran darah pada bagian kaki. Pengaruh terapi rendam kaki air hangat terhadap perubahan tekanan darah pada penderita hipertensi merupakan salah satu therapy yang mudah dan sederhana dilakukan bagi penderita untuk menurunkan Hipertensi. Air hangat mempunyai dampak fisiologis bagi tubuh sehingga rendam kaki air hangat dapat digunakan sebagai salah satu terapi yang dapat memulihkan otot sendi yang kaku serta menyembuhkan stroke apabila dilakukan melalui kesadaran dan kedisiplinan (Peni, 2008). Berdasarkan fenomena tersebut peneliti melakukan penelitian mengenai pengaruh terapi rendam kaki air hangat terhadap perubahan tekanan darah pada ibu hamil hipertensi.

\section{METODOLOGI PENELITIAN}

Penelitian ini menggunakan desain penelitian pre-eksperimen dengan one group pretest-posttest. Penelitian dilaksanakan di wilayah kerja Puskesmas Kahuripan Kota Tasikmalaya pada bulan Januari - Maret 2017.

Populasi dalam penelitian ini adalah semua ibu hamil dengan hipertensi dalam kehamilan yang ada di wilayah kerja Puskesmas Kahuripan pada bulan Januari - Maret 2017 dengan jumlah populasi 24 orang. Teknik pengambilan sampel yang 
dilakukan adalah accidental sampling pada 17 orang responden.

Variabel yang diteliti yaitu karakteristik responden dan besaran tekanan darah pada kehamilan sebelum dan setelah perlakuan terapi rendam kaki. Instrumen yang digunakan selama penelitian adalah lembar observasi, sphygmomanometer dan stetoskop.

Analisis univariat dilakukan untuk mendapatkan gambaran distribusi frekuensi dari variable penelitian. Uji statistik yang digunakan untuk mencari pengaruh terapi rendam kaki air hangat terhadap perubahan tekanan darah pada ibu hamil trimester III menggunakan wilcoxon signed rank test dimana data yang diperoleh tidak berdistribusi normal.

Jika nilai $\rho-$ value $<\alpha(0,05)$, maka

$\mathrm{H}_{0}$ ditolak atau $\mathrm{H}_{\mathrm{a}}$ gagal ditolak. Artinya, variabel tersebut memiliki hubungan yang bermakna. Jika nilai $\rho-$ value $>\alpha(0,05)$, maka $\mathrm{H}_{0}$ gagal ditolak atau $\mathrm{H}_{\mathrm{a}}$ ditolak. Artinya, variabel tersebut tidak memiliki hubungan yang bermakna.

\section{PEMBAHASAN}

Karakteristik Responden

Tabel 1. Distribusi Frekuensi Umur Ibu Hamil Trimester III yang Mengalami Hipertensi

\begin{tabular}{ccc}
\hline Umur & F & $\begin{array}{c}\text { Persentasi } \\
(\%)\end{array}$ \\
\hline$<20$ Tahun & 0 & 0 \\
\hline 20-35 Tahun & 13 & 76,5 \\
\hline$>$ 35 Tahun & 4 & 23,5 \\
\hline Jumlah & 17 & 100 \\
\hline
\end{tabular}

Berdasarkan Tabel 1. menunjukkan bahwa umur ibu hamil trimester III yang mengalami hipertensi di Wilayah Kerja Puskesmas Kahuripan ada pada kategori umur 20-35 tahun yaitu sebanyak 13 orang $(76,5 \%)$
Tabel 2. Distribusi Frekuensi Riwayat Hipertensi Ibu Hamil Trimester III yang Mengalami Hipertensi

\begin{tabular}{ccc}
\hline $\begin{array}{c}\text { Riwayat } \\
\text { Hipertensi }\end{array}$ & F & $\begin{array}{c}\text { Persentasi } \\
(\%)\end{array}$ \\
\hline Gestasional & 15 & 88,2 \\
\hline Kronik & 2 & 11,8 \\
\hline Jumlah & 17 & 100 \\
\hline
\end{tabular}

Berdasarkan Tabel 2. menunjukkan bahwa riwayat hipertensi pada ibu hamil trimester III yang mengalami hipertensi di Wilayah Kerja Puskesmas Kahuripan ada pada kategori gestasional yaitu sebanyak 15 orang $(88,2 \%)$.

Tekanan darah sebelum dan sesudah diberikan terapi rendam kaki air hangat

Tabel 3. Tekanan Darah Sebelum dan Sesudah Terapi Rendam Kaki Air Hangat

\begin{tabular}{lccc}
\hline Intervensi & $\begin{array}{c}\text { Varaibel } \\
\text { T D }\end{array}$ & Mean & Min - max \\
\hline Sebelum & Sistolik & $\begin{array}{c}144,7 \\
\mathrm{mmHg}\end{array}$ & $\begin{array}{c}140-150 \\
\mathrm{mmHg}\end{array}$ \\
\hline & Diastolik & $\begin{array}{c}92,9 \\
\mathrm{mmHg}\end{array}$ & $\begin{array}{c}90-100 \\
\mathrm{mmHg}\end{array}$ \\
\hline Setelah & Sistolik & 129,4 & $120-140$ \\
& & $\mathrm{mmHg}$ & $\mathrm{mmHg}$ \\
\hline & Diastolik & 87,6 & $80-90$ \\
& & $\mathrm{mmHg}$ & $\mathrm{mmHg}$ \\
\hline
\end{tabular}

Berdasarkan Tabel 3 menunjukkan bahwa rata-rata tekanan darah ibu hamil trimester III yang mengalami hipertensi sebelum diberikan terapi rendam kaki air hangat yaitu sistolik sebesar $144,7 \mathrm{mmHg}$, dan diastolik sebesar $92,9 \mathrm{mmHg}$. Ratarata tekanan darah sesudah diberikan terapi rendam kaki air hangat yaitu sistolik sebesar 129,4 $\mathrm{mmHg}$, dan diastolik sebesar $87,6 \mathrm{mmHg}$. Tekanan darah sistolik pada responden sesudah diberikan terapi rendam kaki hangat seluruhnya mengalami perubahan (100\%), sedangkan tekanan darah diastolik sebanyak 10 orang $(58,8 \%)$ mengalami perubahan dan 
sebanyak 7 orang $(41,2 \%)$ tidak mengalami perubahan.

Tabel 4. Pengaruh Terapi Rendam Kaki Air Hangat Terhadap Tekanan Darah pada Ibu Hamil Trimester III

\begin{tabular}{cccc}
\hline $\begin{array}{c}\text { Tekanan } \\
\text { Darah }\end{array}$ & $\begin{array}{c}\text { Mean } \\
\text { Rank }\end{array}$ & $\begin{array}{c}\text { Sum } \\
\text { Rank }\end{array}$ & $\boldsymbol{\rho}$ \\
\hline Sistolik & 9 & 153 & 0,000 \\
\hline Diastolik & 5 & 45 & 0,003 \\
\hline
\end{tabular}

Berdasarkan Tabel 4. menunjukkan bahwa nilai signifikan yang diperoleh sebesar 0,000 untuk tekanan darah sistolik, sedangkan untuk tekanan darah diastolik sebesar 0,003 , jika dibandingkan dengan nilai $\alpha(0,05)$ maka nilai signifikan lebih kecil daripada nilai $\alpha$, maka $\mathrm{H}_{0}$ ditolak yang berarti ada pengaruh terapi rendam kaki air hangat terhadap perubahan tekanan darah pada ibu hamil trimester III yang mengalami hipertensi di Wilayah Kerja Puskesmas Kahuripan Kota Tasikmalaya.

\section{PEMBAHASAN}

Berdasarkan tabel 1. menunjukkan bahwa umur ibu hamil trimester III yang mengalami hipertensi di Wilayah Kerja Puskesmas Kahuripan ada pada kategori umur 20-35 tahun yaitu sebanyak 13 orang $(76,5 \%)$. Usia ibu sangat berpengaruh terhadap proses reproduksi. Dalam kurun waktu reproduksi sehat diketahui bahwa usia yang aman untuk kehamilan dan persalinan adalah usia 20-35 tahun, dimana organ reproduksi sudah sempurna dalam menjalani fungsinya.

Faktor usia berpengaruh terhadap terjadinya hipertensi. Usia wanita remaja pada kehamilan pertama atau nulipara umur belasan tahun (usia muda kurang dari 20 tahun). Usia $20-30$ tahun adalah periode paling aman untuk melahirkan, akan tetapi di negara berkembang sekitar $(10 \%)$ sampai $(20 \%)$ bayi dilahirkan dari ibu remaja yang sedikit lebih besar dari anak-anak.
Berdasarkan tabel 2. menunjukkan bahwa riwayat hipertensi pada ibu hamil trimester III yang mengalami hipertensi di Wilayah Kerja Puskesmas Kahuripan ada pada kategori gestasional yaitu sebanyak 15 orang $(88,2 \%)$. Ibu hamil dengan riwayat hipertensi akan mempunyai risiko yang lebih besar untuk mengalami super imposed preeklamsi. Hal ini karena hipertensi yang diderita sejak sebelum hamil sudah mengakibatkan gangguan/ kerusakan pada organ penting tubuh dan ditambah lagi dengan adanya kehamilan maka kerja tubuh akan bertambah berat sehingga dapat mengakibatkan gangguan/ kerusakan yang lebih berat lagi dengan timbulnya odem dan proteinuria. Keadaan inilah yang disebut dengan super imposed preeklamsi (preeklamsi tidak murni) (Dewi Khresna, 2014).

Berdasarkan tabel 3. menunjukkan bahwa rata-rata tekanan darah ibu hamil trimester III yang mengalami hipertensi sebelum diberikan terapi rendam kaki air hangat yaitu sistolik sebesar $144,7 \mathrm{mmHg}$, diastolik sebesar $92,9 \mathrm{mmHg}$, dan sesudah diberikan terapi rendam kaki air hangat yaitu sistolik sebesar $129,4 \mathrm{mmHg}$, dan diastolik sebesar $87,6 \mathrm{mmHg}$. Dari data tersebut dapat dilihat bahwa terjadi perubahan tekanan darah sebelum dan sesudah diberikan terapi rendam kaki air hangat.

Berdasarkan hasil penelitian menunjukkan bahwa tekanan darah sistolik pada pada ibu hamil yang mengalami hipertensi sesudah diberikan terapi rendam kaki hangar seluruhnya mengalami perubahan (100\%), sedangkan tekanan darah diastolik sebanyak 10 orang $(58,8 \%)$ mengalami perubahan dan sebanyak 7 orang $(41,2 \%)$ tidak mengalami perubahan.

Hipertensi adalah peningkatan tekanan sistolik sekurang-kurangnya 30 $\mathrm{mmHg}$, atau peningkatan tekanan diastolik sekurang-kurangnya $15 \mathrm{mmHg}$. Seseorang dikatakan menderita tekanan darah tinggi atau hipertensi yaitu apabila tekanan darah sistolik > $140 \mathrm{mmHg}$ dan diastolik > 90 mmhg (Rukiyah danYulianti, 2010). 
Tekanan darah adalah suatu tenaga yang digunakan atau dipakai oleh darah yang dipompakan dari jantung ke seluruh jaringan tubuh melalui darah. Tekanan darah ini sifatnya tidak tetap. Tekanan darah akan berubah-ubah sesuai dengan aktivitas tubuh maupun keadaan psikologis seseorang, pada saat aktivitas meningkat atau dalam suasana stres tekanan darah akan meningkat, sebaliknya dalam suasana istirahat, santai atau rileks, tekanan darah akan menurun. Sebagai contoh pada malam hari tekanan darah cenderung turun, sedangkan disepanjang hari akan naik. Bila tekanan darah selalu tinggi dalam situasi apapun dalam waktu lama, seseorang dapat dikatakan menderita tekanan darah tinggi (Hardi, 2009).

Berdasarkan hasil penelitian menunjukkan terdapat pengaruh terapi rendam kaki air hangat terhadap perubahan tekanan darah pada ibu hamil trimester III yang mengalami hipertensi di Wilayah Kerja Puskesmas Kahuripan Kota Tasikmalaya.

Hipertensi dapat diobati secara farmakologis dan non-farmakologis. Pengobatan secara farmakologis biasanya menggunakan obat-obatan yang mengandung efek samping. Pengobatan secara non-farmakologis salah satunya dapat dilakukan dengan mengubah gaya hidup yang lebih sehat, melakukan olahraga, diet rendah garam dan melakukan terapi dengan rendam kaki menggunakan air hangat yang bisa dilakukan setiap saat. Para penderita hipertensi kebanyakan hanya mengkonsumsi obat-obatan dan menghindari makanan asin saja untuk menurunkan tekanan darah, sedangkan tindakan pemberian terapi rendam kaki air hangat belum pernah dilakukan dan sampai saat ini pengaruhnya terhadap perubahan tekanan darah masih belum dijelaskan.

Air hangat mempunyai dampak fisiologis bagi tubuh Pertama berdampak pada pembuluh darah dimana hangatnya air membuat sirkulasi darah menjadi lancar, kedua faktor pembebanan di dalam air akan menguatkan otot-otot dan ligament yang mempengaruhi sendi tubuh, sehingga rendam kaki air hangat dapat digunakan sebagai salah satu terapi yang dapat memulihkan otot sendi yang kaku serta menyembuhkan stroke apabila dilakukan melalui kesadaran dan kedisiplinan (Kusumaastuti, 2008).

\section{KESIMPULAN}

Perubahan tekanan darah ibu hamil trimester III yang mengalami hipertensi di Wilayah Kerja Puskesmas Kahuripan yaitu untuk sistolik mengalami penurunan sebesar (100\%), sedangkan diastolik mengalami penurunan sebesar $(58,8 \%)$, dan $(41,2 \%)$ tetap.

Ada pengaruh terapi rendam kaki air hangat terhadap perubahan tekanan darah pada ibu hamil III yang mengalami hipertensi di Wilayah Kerja Puskesmas Kahuripan Kota Tasikmalaya.

\section{SARAN}

Hasil penelitian ini diharapkan dapat menambah dan meningkatkan wawasan serta ilmu pengetahuan untuk tenaga kesehatan terutama bidan dalam pengelolaan kasus hipertensi khususnya pada ibu hamil dapat dilakukan secara non-farmakologi yaitu dengan menggunakan terapi rendam kaki air hangat.

\section{DAFTAR PUSTAKA}

Anonim, (2016). Keluarga mau fresh ayo rendam kaki dengan air hangat. http://liputanislam.com Diakses 13 September 2016.

Anonim, (2014). Inilah manfaat merendam kaki dengan air hangat. http://www.beringaz.com Diaskses 15 September 2016.

Boegyss K., (2013). Rendam kakidengan air hanga. http://karmanboegyss.co.id Diakses 12 September 2016. 
Dewi \& Sunarsih, (2012). Asuhan

Kehamilan Untuk Kebidanan. Salemba Medika: Jakarta.

Indriyani, D., (2013). Maternitas Pada Area Perawatan Antenatal. Graha IImu: Yogyakarta.

Khotimah, (2011). Pengaruh Rendam Air Hangat Pada Kaki Dalam Meningkatkan Kuantitas Tidur Lansia.http://www.journal.unipdu.ac.id/i ndex.php/seminas/article/view/162. Diakses 20 September 2016.

Kriebs J.M. \& Gegor C.L., (2010). Buku Saku Asuhan Kebidanan Varney. Ed 2. Kedokteran EGC: Jakarta

Notoatmodjo, (2010). Metodologi Penelitian Kesehatan. Ed.rev. Rineka Cipt: Jakarta.

Novita W., (2009). Buku Pintar Merawat Kecantikan Di Rumah. PT Gramedia Pustaka Utama. Jakarta

Rifai M., (2015). Hydrotherapy Air Panas. http://rifaibloger.blogspot.co.id/2015/04/ karya-tulis-ilmiah-hydro-therapy.html. Diaskses 15 September 2016.

Rukiyah \& Yulianti, (2010). Asuhan Kebidanan IV Patologi Kebidanan.TIM:. Jakarta.

Saifudin \& Wiknjosastro, (2010). IImu Kebidanan. PT Bina Pustaka Sarwono Prawirohardjo: Jakarta

Santoso D.A., (2015). Pengaruh Terapi Rendam Kaki Air Hangat Terhadap Penurunan Tekanan Darah Pada Lansia Penderita Hipertensi di Wilayah Kerja UPK Puskesmas Khatulistiwa Kota Pontianak. http://download.portalgaruda.org. Diakses 01 Oktober 2016.

Sihotang P.C, Rahmayanti E.I, Tebisi J.M., \& Bantulu F.M., (2016). Hubungan Pola Makan dan Kecukupan Istirahat Tidur Dengan Kejadian Hipertensi Pada lbu Hamil di Wilayah Kerja Puskesmas Biromaru. http://jurnal.untad.ac.id/jurnal/index.php/ HealthyTadulako/article/view/5747. Diakses 30 September 2016.

Soenanto H., (2009). 100 Resep Sembuhkan Hipertensi, Asam Urat, dan
Obesitas. PT Elex Media Komputindo. Jakarta.

Sugiyono, (2009). Metode Penelitian Kuantitatif, Kualitatif, dan R\&D. Alfabeta: Bandung.

Supriyadi \& Gunawan, (2012). Kapita Selekta Kedaruratan Obstetri dan Ginekologi. EGC: Jakarta.

Susanti S., (2015). Aplikasi Terapi Rendam Kaki Air Hangat Terhadap Perubahan Tekanan Darah Pada Ibu Hamil yang Menderita Hipertensi di RSUD Kota Semarang. http://digilib.unimus.ac.id/gdl. Diakses 17 September 2016.

Umah K, R. Lina M., Christina L., (2012). Pengaruh Terapi Rendam Kaki Air Hangat Terhadap Perubahan Tekanan Darah Pada Penderita Hipertensi. https://ikhaasyik.wordpress.com/2014/0 2/02/analisa-jurnal/. Diakses 30 September 2016.

Varney H., (2007). Buku Ajar Asuhan Kebidanan. Ed. 4. Kedokteran EGC: Jakarta. 